\title{
Pengembangan Modul Berbasis Discovery-Inquiry untuk Fisika SMA Kelas XII Semester 2
}

\author{
Upik Rahma Fitri ${ }^{1, a)}$, Desnita ${ }^{2}$, Erfan Handoko ${ }^{2}$ \\ ${ }^{1}$ Program Studi Magister Pendidikan Fisika, Universitas Negeri Jakarta, Jakarta 13220 \\ ${ }^{2}$ Program Studi Pendidikan Fisika, Jurusan Fisika, Universitas Negeri Jakarta, Jakarta 13220 \\ Email: ${ }^{\text {a) }}$ upik.rahma.fitri@gmail.com
}

\begin{abstract}
Research aimed at developing the Discovery Inquiry-based module for high school physics class XII second half of this is a study that is based on that of high school students has not yet fully meet the needs of adequate facilities. The method used is a method of research and development. In the implementation of the study outlines the development of research carried out in two stages: Theoretical and Empirical. The result of this research is a module that has been developed and can be used by high school students or equivalent that will conduct independent study about the physics of atomic nuclei and radioactivity. From the results of the validation test results were obtained expert grouped into three, namely the assessment of media experts at $81 \%, 83.6 \%$ material experts, and validation of professional teachers with the results of 90\%. Implementation of modules in SMAN 9 Jakarta indicate that the module has been able to boost the students' cognitive value with an increase of 10.23 points. Based on the results of this study concluded that, modules developed that is based Discovery Inquiry has met the criteria so that modules can be used in self-learning.
\end{abstract}

Keywords: Learning, Modules, Development, Discovery Inquiry

\begin{abstract}
Abstrak
Penelitian yang bertujuan mengembangkan Modul berbasis Discovery Inquiry untuk fisika SMA kelas XII semester 2 ini merupakan penelitian yang didasarkan bahwa siswa SMA belum sepenuhnya mendapat fasilitas pemenuhan kebutuhan yang mencukupi. Metode penelitian yang digunakan adalah metode penelitian pengembangan (Research and Development). Dalam pelaksanaan penelitian secara garis besar penelitian pengembangan dilaksanakan dalam dua tahap yaitu Teoritik dan Empiris. Hasil penelitian ini adalah sebuah modul yang sudah dikembangkan dan dapat digunakan oleh siswa SMA atau sederajat yang akan melakukan pembelajaran fisika secara mandiri tentang inti atom dan radioaktivitas. Dari hasil uji validasi ahli didapatkan hasil yang dikelompokan menjadi 3 yaitu penilaian dari ahli media sebesar $81 \%$, ahli materi sebesar $83,6 \%$, dan validasi guru profesional dengan hasil $90 \%$. Implementasi modul di SMAN 9 Jakarta menunjukkan bahwa modul telah mampu menigkatkan nilai kognitif siswa dengan peningkatan sebesar 10,23 point. Berdasarkan hasil penelitian dapat disimpulkan bahwa, modul yang dikembangkan yaitu berbasis Discovery Inquiry telah memenuhi kriteria modul sehingga dapat digunakan pada pembelajaran mandiri.
\end{abstract}

Kata-kata kunci: Pembelajaran, Modul, Pengembangan, Discovery Inquiry 


\section{PENDAHULUAN}

Perkembangan zaman memberi dampak akan naiknya tingkat kebutuhan manusia terhadap pendidikan yang berkualitas dan efektif. Dalam penelitiannya (Sudji, 2010) mengemukakan bahwa terdapat pergeseran paradigma perubahan belajar seperti pernyataan TABEL 1 berikut ini:

TABEL 1. Perubahan Paradigma Belajar

\begin{tabular}{ll}
\hline Tradisional learning & New learning \\
\hline Teacher centered & Student centered \\
Single media & Multimedia \\
Isolated work & Collaborative \\
Information delivery & Information exchange \\
Factual, knowledge based & Criical thingking ang \\
Learning decision & Informed making \\
Push & Pull \\
\hline
\end{tabular}

Pergeseran paradigma perubahan belajar mengantarkan kepada model metode belajar discovery Inquiry. Menurut penelitiannya (Triania) metode Discovery Inquiry adalah salah satu metode pengajaran yang memungkinkan siswa terlibat secara aktif menggunakan proses mentalnya untuk menemukan beberapan konsep dan prinsip materi yang sedang dipelajari. Inquairy dibentuk dan meliputi discovery, karena siswa harus mengguanakan kemampuan discovery dan lebih banyak lagi. Dengan kata lain, inquiry adalah suatu perluasan proses-proses discovery yang digunakan dengan cara lebih dewasa. Metode discovery inquiry merupakan metode yang dapat dipilih untuk pengajaran IPA dan matematika, mengingat dalampengajaran IPA dan matematika diperlukan suatu bentuk kegiatan yang dapat mengarahkan siswa untuk dapat menemukan suatu konsep melalui pengujian atau penemuan secara langsung. Salah satu model pembelajaran yang diprediksi dapat melatihkan keterampilan berpikir rasional siswa ialah model pembelajaran discovery-inquiry yang pada hakikatnya merupakan penggabungan model pembelajaran discovery dan inquiry

Pada peneltiannya (Carl:2001) meyebutkan bahwa pada model pembelajaran Discovery Inquriy help student develop concepts on the basis of teacher-directed experinences.Pada penelitiannya (Spencer) menyebutkan Inquiry can be defined as a process that is used to resolve uncertainty by examining an individual's ideas and beliefs. Langkah-langkah pembelajaran berbasis Discovery Inquiry, dimana langkah -langkah kegiatan ini mendukung peserta didik, yakni : a) Secara instintif, siswa selalu ingin tahu; b) Dalam percakapan, siswa selalu ingin berbicara dan mengkomunikasikan idenya; c) Dalam mebangun (konstruksi) pengetahuan, siswa selalu ingin membuat sesuatu; d) Siswa selalu mengekspresiakan diri; e) Perkembangan intelektual peserta didik.

Dalam penelitiannya (Nuryani:2005) kemampuan dasar bekerja ilmiah sesungguhnya perluasan dari metode ilmiah yang diterapkan dalam tindakan belajar IPA maupun dalam kehidupan. Kemampuan dasar bekerja ilmiah terdiri atas kecerdasan intelektual dan kecerdasan emosional. Dalam pembelajaran dapat dilakukan melalui pemberian pengalaman dalam bentuk kegiatan mandiri atau kelompok kecil.

Perlunya guru merancang pembelajaran sains yang berbasis discovery Inquiry telah lama ditekankan oleh pakar pendidikan dan pakar pendidikan sains. Kemampuan dasar bekerja ilmiah (Saraswati:2003) melakukan penelitian tindakan kelas dengan model latihan inquiry pada konsep rangkaian listrik dalam upaya menumbuhkan keberanian siswa untuk mengajukan pertanyaan dan mengemukakan gagasan siswa kelas 3 SLTP, sebanyak dua siklus dengan dua tindakan untuk masing-masing siklus. Hasil penelitiannya telah tumbuh keberanian keberanian siswa untuk mengajukan pertanyaan dan mengemukakan gagasan selama dua siklus dengan hasil siklus pertama $42 \%$ dan siklus kedua $55 \%$. Pada jenjang pedidikan menengah banyak berisikan keterampilan proses yang mencangkup keterampilan mengajukan pertanyaan, melakukan pengamatan, mengelompokan, melakukan inferensi, memprediksi, menafsirkan, merencanakan, menggunakan alat dan bahan, berkomunikasi, dan berhipotesis. Maka pada jenjang Sekolah Menengah diperlukan metode discovery Inquiry yang dapat meningkatkan keterampilan proses sains. Pada penelitannya (Rustaman:2003) bahwa penerapan metode discovery inquiry menunjukan penguasaan ketrampilan proses yang lebih tinggi. 
Selain metode pembelajaran, media mempunyai peran penting. dari berbagai media pembelajaran yang tersedia, media berbasis cetakan adalah media yang mudah untuk digunakan secara mandiri. Menurut peneltiannya (Ricu:2012) dengan penggunaan modul sebagai bahan ajar di SMP berpengaruh signifkan terhadap aktivitas belajar mengajar dengan skor respon siswa 3,6 dari skala 4 . (suhartati:2012) menerapkan penggunaan bahan ajar modul pada mata pelajaran matematika. Di dapatkan hasil penelitian yang signifikan yaitu pre test sebesar 4,64 dan setelah menggunakan bahan ajar cetakan post test sebesar 8,71. Kedua penelitian tersebut menyimpulkan bahwa penggunaan modul secara nyata dapat meningkatkan respon dan hasil belajar siswa.

\section{METODE PENELITIAN}

Metode penelitian yang digunakan adalah metode penelitian dan pengembangan (R\&D). Metode ini bertujuan untuk mengembangkan dan menghasilkan sebuah produk modul yang sudah ada dengan pengembangan berbasis discovery inquiry. Pembuatan modul berbasis discovery inquiry berguna menunjang proses pembelajaran fisika serta sesuai pada pokok bahasan inti atom radioaktivitas. Adapun langkah penelitiannya sebagai berikut.

a) Research and information collecting; termasuk dalam langkah ini antara lain studi literatur yang berkaitan dengan permasalahan yang dikaji, dan persiapan untuk merumuskan kerangka kerja penelitian;

b) Planning; termasuk dalam langkah ini merumuskan kecakapan dan keahlian yang berkaitan dengan permasalahan, menentukan tujuan yang akan dicapai pada setiap tahapan, dan jika mungkin/diperlukan melaksanakan studi kelayakan secara terbatas;

c) Develop preliminary form of product, yaitu mengembangkan bentuk permulaan dari produk yang akan dihasilkan. Termasuk dalam langkah ini adalah persiapan komponen pendukung, menyiapkan pedoman dan buku petunjuk, dan melakukan evaluasi terhadap kelayakan alatalat pendukung;

d) Preliminary field testing, yaitu melakukan uji coba lapangan awal dalam skala terbatas. dengan melibatkan subjek sebanyak $6-12$ subjek. Pada langkah ini pengumpulan dan analisis data dapat dilakukan dengan cara wawancara, observasi atau angket;

e) Main product revision, yaitu melakukan perbaikan terhadap produk awal yang dihasilkan berdasarkan hasil uji coba awal. Perbaikan ini sangat mungkin dilakukan lebih dari satu kali, sesuai dengan hasil yang ditunjukkan dalam uji coba terbatas, sehingga diperoleh draft produk (model) utama yang siap di uji coba lebih luas;

f) Main field testing, uji coba utama yang melibatkan seluruh mahasiswa.

g) Operational product revision, yaitu melakukan perbaikan/penyempurnaan terhadap hasil uji coba lebih luas, sehingga produk yang dikembangkan sudah merupakan desain model operasional yang siap divalidasi;

h) Operational field testing, yaitu langkah uji validasi terhadap model operasional yang telah dihasilkan;

i) Final product revision, yaitu melakukan perbaikan akhir terhadap model yang dikembangkan guna menghasilkan produk akhir (final);

j) Dissemination and implementation, yaitu langkah menyebarluaskan produk/model yang dikembangkan.

Modul berbasis discovery inquiry yang telah diuji ahli memenuhi kriteria sebuah modul berbasis discovery inquiry dan dapat digunakan atau di uji coba oleh siswa SMA. Penelitian ini juga digunakan untuk mengukur dampak penggunaan modul berbasis discovery inquiry dalam kegiatan discovery inquiry pada proses belajar fisika. Populasi yang digunakan adalah satu kelas XII IPA salah satu SMA di jakarta. Dengan menyebarkan modul kepada siswa tersebut kemudian menjawab pertanyaan dengan enam kategori langkah-langkah discovery inquiry

Validasi dalam penelitian dilakukan oleh dosen ahli, ahli media, dan guru-guru fisika profesional untuk mengetahui bahwa modul ini dikembangkan dengan berbasis Discovery Inquiri. Diharapkan alat ukur ini benar sesuai standar sehingga penggunaanya dapat dipertanggungjawabkan. 
TABEL 2. Skala Penilaian Instrumen

\begin{tabular}{llcc}
\hline \multirow{2}{*}{ No } & \multirow{2}{*}{ Alternatif Jawaban } & \multicolumn{2}{c}{ Bobot Skor } \\
& Positif $(+)$ & Negatif (-) \\
\hline 1 & Sangat Baik & 5 & 1 \\
2. & Baik & 4 & 2 \\
3 & Cukup & 3 & 3 \\
4 & Tidak Baik & 2 & 4 \\
5 & Sangat Tidak Baik & 1 & 5 \\
\hline
\end{tabular}

\section{HASIL DAN PEMBAHASAN}

Berdasarkan hasil uji kelayakan pada modul berbasis discovery inquiry didapatkan hasil dari ahli media, materi, dan guru.

TABEL 3. Uji Ahli Media

\begin{tabular}{cccc}
\hline NO & ASPEK & I MADE ASTRA & IWAN SUGIHARTONO \\
\hline 1 & TAMPILAN & $80 \%$ & $82 \%$ \\
2 & BAHASA & $80 \%$ & $80 \%$ \\
\hline
\end{tabular}

Berdasarkan TABEL 3 didapatkan hasil uji kelayakan media dengan yaitu sebesar 80,5\%. Dengan didapatkan presentase tersebut maka kelayakan media pada rentan $80-100 \%$ yaitu mendapai kriteria sangat baik.

TABEL 4. Uji Ahli Materi

\begin{tabular}{ccccc}
\hline NO & ASPEK & SUKRO MUHAB & ALIMUDIN & SUPRIYADI \\
\hline 1 & ISI & $79 \%$ & $98 \%$ & $74 \%$ \\
\hline
\end{tabular}

Berdasarkan TABEL 4 di atas makan disimpulkan bahwa modul ini mendapatkan hasil kelayakan isi sebesar $79 \%$ untuk penguji pertama, $98 \%$ untuk penguji keddua dan $74 \%$ pada penguji ke 3. Maka presentasi secara keseluruhan untuk presentase uji kelayakan materi yaitu sebesar 83,7\%. Dengan didapatkan presentase tersebut maka kelayakan media pada rentan $80-100 \%$ yaitu mendapai kriteria sangat baik.

TABEL 5. Uji Kelayakan Guru

\begin{tabular}{ccccc}
\hline NO & VALIDASI GURU FISIKA & ISI & BAHASA & TAMPILAN \\
\hline 1 & Suparman & $95 \%$ & $97 \%$ & $100 \%$ \\
2 & Penina & $83 \%$ & $87 \%$ & $80 \%$ \\
3 & Heru & $91 \%$ & $87 \%$ & $90 \%$ \\
\hline
\end{tabular}

\section{GURU FISIKA}

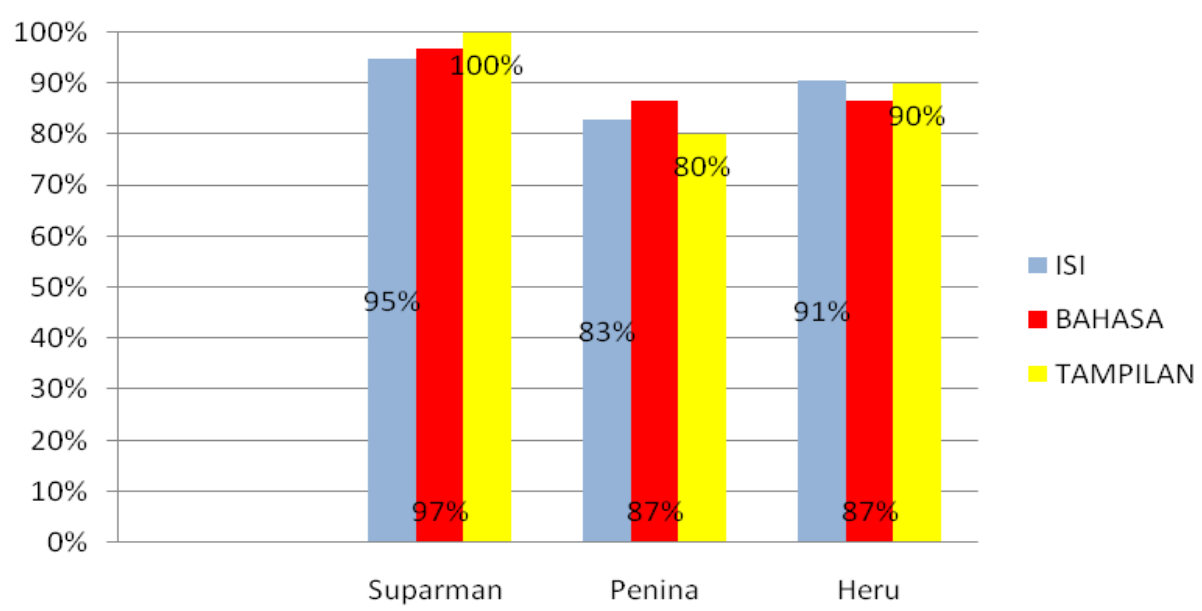

GAMBAR 1. Hasil Uji Kelayakan Guru 
Berdasarkan TABEL 5 dan GAMBAR 1 di atas maka disimpulkan bahwa modul ini mendapatkan hasil dari uji guru pertama untuk aspek isi sebesar sebesar 95\%, aspek bahasa sebesar $87 \%$ dan aspek tampilan sebesar $100 \%$. Pada penguji guru kedua untuk aspek isi sebesar sebesar 83\%, aspek bahasa sebesar $87 \%$ dan aspek tampilan sebesar $80 \%$. Pada penguji guru ketiga untuk aspek isi sebesar sebesar $91 \%$, aspek bahasa sebesar $87 \%$ dan aspek tampilan sebesar $90 \%$. Maka presentasi secara keseluruhan untuk presentase uji kelayakan pada guru SMA yaitu sebesar 87,33\%. Dengan didapatkan presentase tersebut maka kelayakan pada guru SMA pada rentan 80\%-100\% yaitu mendapai kriteria sangat baik.

TABEL 6. Uji Skala Kecil

\begin{tabular}{ccc}
\hline NO & ASPEK & PERSENTASE \\
\hline 1. & Isi & $71 \%$ \\
2. & Bahasa & $75 \%$ \\
3. & Tampilan & $80 \%$ \\
\hline
\end{tabular}

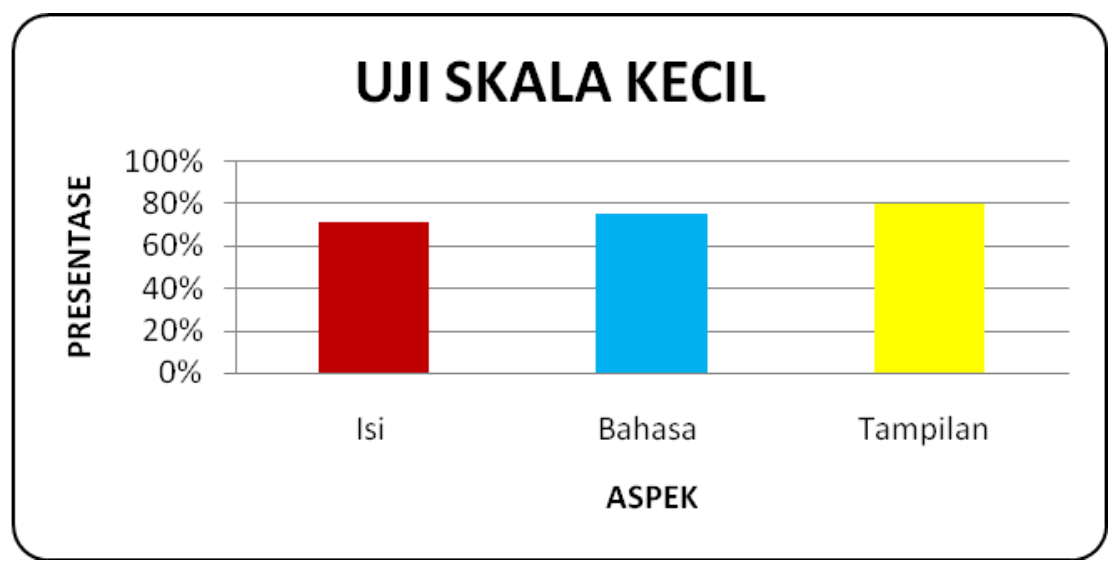

GAMBAR 2. Uji Skala Kecil

Berdasarkan TABEL 6 dan GAMBAR 2 pada uji coba skala kecil kepada 5 orang siswa didapatkan hasil bahwa respon siswa terhadap isi modul tersut adalah sebesar $71 \%$, kebudahan siswa dalam memahami bahasa adalah sebesar $75 \%$ dan ketertarikan siswa terhadap tampilan adalah sebesar $80 \%$. Dari data diatas maka dapat disimpulkan bahwa respon siswa sebesar 75,33\% terhadap penggunaan modul berbasis Discovery Inquiry. Dengan presentase tersebut maka kriteria modul untuk dengan melihat respon pengguna adalah pada rentan $60-80 \%$ yaitu baik.

TABEL 7. Uji Skala Besar

\begin{tabular}{ccc}
\hline NO & ASPEK & PERSENTASE \\
\hline 1. & Isi & $79 \%$ \\
2. & Bahasa & $82 \%$ \\
3. & Tampilan & $84 \%$ \\
\hline
\end{tabular}

Berdasarka TABEL 7 pada uji implementasi kepada 30 orang siswa didapanka hasil bahwa respon siswa terhadap isi modul tersut adalah sebesar $79 \%$, kebudahan siswa dalam memahami bahasa adalah sebesar $82 \%$ dan ketertarikan siswa terhadap tampilan adalah sebesar $84 \%$. Dari data diatas maka dapat disimpulkan bahwa respon siswa sebesar 81,67 \% terhadap penggunaan modul berbasis Discovery Inquiry. Dengan presentase tersebut maka kriteria modul untuk dengan melihat respon pengguna adalah pada rentan $80-100 \%$ yaitu sangat baik.

Berdasarkan hasil implemetasi tahap 1 maka diperoleh hasil penilaian kognitif siswa yaitu ratarata sebesar 66,66, hal ini membuat saya melakukan revisi pada modul tersebut untuk mlihat meningkatnya hasil kognitif siswa. Perubahan tersebut pada isi materi modul tersebut agar siswa dapat mudah memahami kalimat yang di bacanya ataupun contoh soal yang terdapat pada modul tersebut. 
TABEL 8. Nilai Uji Implementasi Tahap 1

\begin{tabular}{|c|c|c|c|c|c|c|c|c|c|c|}
\hline \multirow{2}{*}{\multicolumn{2}{|c|}{$\begin{array}{c}\text { NO. } \\
\text { UJI SKALA KECIL }\end{array}$}} & \multicolumn{6}{|c|}{$\begin{array}{c}\text { LANGKAH-LANGH } \\
\text { DISCOVERY INQUIRY }\end{array}$} & \multirow{2}{*}{ SKOR } & \multirow{2}{*}{$\begin{array}{l}\text { SKOR } \\
\text { MAKS }\end{array}$} & \multirow[t]{2}{*}{$\begin{array}{l}\text { NILAI } \\
\text { AKHIR }\end{array}$} \\
\hline & & $\mathbf{A}$ & $\mathbf{B}$ & $\mathbf{C}$ & D & $\mathbf{E}$ & $\mathbf{F}$ & & & \\
\hline JUMLAH & 30 & 16 & 15 & 17 & 17 & 17 & 18 & 100 & 150 & 333,333 \\
\hline \multicolumn{2}{|l|}{ SKOR } & $\mathbf{A}$ & $\mathbf{B}$ & $\mathbf{C}$ & $\mathbf{D}$ & $\mathbf{E}$ & $\mathbf{F}$ & $\begin{array}{l}\text { SKOR } \\
\text { MAKS }\end{array}$ & & \multirow{3}{*}{66,66} \\
\hline \multicolumn{2}{|c|}{ SKOR MNIMAL } & 2 & 2 & 2 & 2 & 2 & 2 & 12 & & \\
\hline \multicolumn{2}{|c|}{ SKOR MAKSIMAL } & 5 & 5 & 5 & 5 & 5 & 5 & 30 & & \\
\hline
\end{tabular}

Berdasarkan hasil implemetasi tahap 1 maka diperoleh hasil penilaian kognitif siswa yaitu ratarata sebesar 76,89, hal ini menunjukan bahwa ada peningkatan dari kognitif siswa sebesar 10,23 point dengan meningkatnya nilai siswa maka produk modul ni dinilai juga menigkatkan pemahaman siswa terhadap konsep yang disajikan.

TABEL 9. Nilai Uji Implementasi Tahap 2

\begin{tabular}{|c|c|c|c|c|c|c|c|c|c|}
\hline \multirow{2}{*}{$\begin{array}{c}\text { NO. } \\
\text { IMPLEMENTASI }\end{array}$} & \multicolumn{6}{|c|}{$\begin{array}{c}\text { LANGKAH-LANGH } \\
\text { DISCOVERY INQUIRY }\end{array}$} & \multirow{2}{*}{ SKOR } & \multirow{2}{*}{$\begin{array}{l}\text { SKOR } \\
\text { MAKS }\end{array}$} & \multirow[t]{2}{*}{$\begin{array}{l}\text { NILAI } \\
\text { AKHIR }\end{array}$} \\
\hline & $\mathbf{A}$ & B & $\mathbf{C}$ & D & $\mathbf{E}$ & $\mathbf{F}$ & & & \\
\hline JUMLAH & 103 & 118 & 115 & 115 & 116 & 125 & 692 & 870 & 2306,67 \\
\hline SKOR & $\mathbf{A}$ & B & $\mathbf{C}$ & D & $\mathbf{E}$ & $\mathbf{F}$ & $\begin{array}{l}\text { SKOR } \\
\text { MAKS }\end{array}$ & & \multirow{3}{*}{76,89} \\
\hline SKOR MNIMAL & 2 & 2 & 2 & 2 & 2 & 2 & 12 & & \\
\hline SKOR MAKSIMAL & 5 & 5 & 5 & 5 & 5 & 5 & 30 & & \\
\hline
\end{tabular}

\section{KESIMPULAN}

Telah dikembangkan media pembelajaran pendukung berupa modul fisika berbasis discovery inquiry dengan menggunakan metode penelitian pengembangan (research and development) melalui tahap analisis kebutuhan, tahap pengembangan produk, dan tahap uji coba produk. Hasil uji coba modul yang telah dikembangkan kepada para pengkaji (materi, media dan guru). Dengan demikian modul yang dikembangkan dapat dijadikan sebagai modul pembelajaran fisika secara mandiri.

Kelebihan pada modul fisika berbasi Discovery Inquiry yaitu pada kegiatan langkah-langkah yang sudah mengadopsi langkah-langkah pembelajaran Discovey Inquiry. Selain itu modul dilengkapi dengan materi dan kasus yaang dapat dijadikan bahan pembelajaran mandiri. Desain alat modul yang dihasilkan semakin mudah di pahami sehingga modul ini daat dipakai oleh pengguna sebagai bahan pembelajaran mandiri.

Modul pembelajaran berbasis discovery-inquiry secara keseluruhan telah layak digunakan dan efektif untuk digunakan pada pemeblajaran mandiri siswa SMA kelas XII, hal ini dilihat dari uji kelayakan dan nilai evaluasi (kognitif ) pengguna modul ditinjau dari kegiatan menemukan masalah, merumuskan masalah, merumuskan hipotesis, mengumpulkan data, menguji hpotesis dan merumuskan kesimpulan. Modul berbasis discovery-inquiry mendapatkan tanggapan positif dari siswa, hampir semua siswa sampel penelitian menyatakan senang dan mendapatkan hal positif dari modul berbasis discovery-inquiry.

\section{UCAPAN TERIMAKASIH}

Terimakasih kepada: Kepala SMAN 9 Jakarta, Bapak Budi selaku guru fisika SMAN 9 Jakarta, Guru dan Staf serta Karyawan SMAN 9 Jakarta yang telah mengizinkan dan mendukung kegiatan penelitian ini, serta kepada siswa dan siswi kelas XII-IPA atas kerjasamanya, Bapak Alimudin yang telah bersedia membimbing saya dalam melakukan penelitian materi inti atom dan radio aktifitas, serta RSUP Persahabatan yang telah mengizinkan untuk mengadakan penelitian di departemen radioterapi. 


\section{REFERENSI}

Akhdi, Mukhlis. 2010. Pengetahuan Dasa Untuk Membaca dan Memanfaatkan Peta Nuklida. Jurnal BATAN

Arsyad, Azhar. (2011). Media Pembelajaran. Jakarta: Rajagrafindo Persada.

Arsyar, Rayandra. (2011). Kreatif Mengembangkan Media Pembelajaran. Jakarta: Gunung Persada Press.

Balim, A., G. (2009). The Effects of Discovery Learning on Students' Success and Inquiry Learning Skills. Turkey : Journal of fakulty of Education.

Belawati, Tian, dkk. (2003). Pengembangan Bahan Ajar. Jakarta: Pusat Penerbita Universitas Terbuka.

Budiyanto, Joko. (2008). FISIKA SMA KELAS XII. Pusat Perbukuan Departemen Pendidikan: Jakarta.

Carl J. Wenning, ed.D. Levels of Inquiry Model of Science Teahing : Learning Sequences to Lessons Plans. USA: Journal of Illinois State University.

Departemen pendidikan nasional. (2003). Buku Pedoman Penulisan Modul. Direktorat pendidikan menengah Kejuruan Direktorat Jendral Pendidikan Dasar dan Menengah. Jakarta: Depdiknas.

Djamarah, Syaiful Bhari. (2006). Strategi Belajar Mengajar. Jakarta: Rineka Cipta.

Yulianti. (2012). Penerapan Virtual Experiment Berbasis Inkuiri untuk Mengembangkan Kemandirian Mahasiswa. Semarang: jurnal fisika Universitas Negeri Semarang.

Gall, M.D., J.R. \& Borg, W.R. (2003). Educational Research. Boston: Pearson Educational, Inc.

Hamdani, M.A. ( 2011). Strategi Belajar Mengajar. Bandung: Pustaka Setia

Harsanti, Tria. (2013). Pengembangan Modul Fisika Kontekstual sebagai Bahan Ajar pada Pokok Bahasan Fluida SMA. Jakarta: Skripsi Universitas Negeri Jakarta

Hanafiah, Nanang \& Suhana, Cucu. (2011). Konsep Strategi Pembelajaran. Bandung: Refika Aditama.

IAEA. 2003. Manual For Reactor Produced Radiousotop. Austria

Janine Swaak., Jong, De, Ton., dkk. The Effects Of Discovery Learning and Expository Instruction on The Acquitisionof Defenitional and Intuitive Knowledge. Netherlands: Journal of University of Twente.

Jufri, Wahab. (2013). Belajar dan Pembelajan Sains. Bandung: Pustaka Reka Cipta

K, Blaum. 2005. Nuclear and Particle Physics. Journal of Physics volume 31 Nomor 10: IOP

Kristianti, Budi Santoso. 2012. Perancangan Ruangan Radioterpai Eksternal Menggunakan Cobalt60. Jurnal Perangkat Nuklir Volume 6 Nomor 2: Jakarta

Chew, Charles, dkk. (2008). Physics Matters. Singapur: Marshall Cavendish Education

McBride, W, John, dkk. Using an Inquiry Approach to Teach Science to Secondary School Science Teachers. Texas: journal of University of Texas-Pan American.

Munadi, Sudji,. Sunarto, Sunaryo. Pengembangan Modul Pembelajaran Konstruktivistik Kontekstual Berbantuan Komputer Dalam Mata Diklat Pemesinan. Yogyakarta: Jurnal Universitas Negeri Yogyakarta.

Prastowo, Andi. (2011). Panduan Kreatif Membuat Bahan Ajar Inovatif. Jogjakarta: DIVA pres.

Rahmatika Dewi, Aulia. Pengembangan Modul Pembelajaran Fisika inti Berbsis Multimedia dengan Swisshmax Sebagai Media Belajar Mandiri. Jurnal UNM: Malang. 
Reedy C, Robert. 2012. Nucile Production By Primary - Ray Proton. Journal of Geophysical : American

Rizema, Sitiava., P. (2013). Desain Belajar Mengajar Kreatif Berbasis Sains. Jogjakarta: DIVA pres.

Rustaman, Y., Nuryani. Perkembangan penelitian Pembelajaran Berbasis Inkuiri Dalam Pendidikan Sains. Bandung: Jurnal Universitas Pendidikan Indonesia.

Sayodih, Nana. (2011). Metode Penelitian Pendidikan. Jakarta: Rosda.

Sari, Ika Kurnia. (2013). Pengembangan Modul Kontekstual sebagai Bahan Ajar Fisika Materri Wujud Zat dan Perubahannya Kelas VII SMP. Jakarta: skripsi Universitas Negeri Jakarta.

Santoso, Wiranto budi. 2012. Desain Perangkat Radioterapi Eksternal Menggunakan Cobalt-60. Jurna Nuklir Volume 6 Nomor 2: jakarta.

Sidiq, Ricu. (2012). Pengembangan Modul Elktronik Sejaran untuk SMP. Jakarta: Disertadi Universitas Negeri Jakarta.

Spencer, L, Trina \& Walker, M, Tracy. Creating a Love for Science for elemntary Students Through Inquiry-Based Learning. Virginia: Journal of Virginia Science Education.V4, N2.

Suhartati, tri. (2012). Pengembangan Bahan Ajar Matematika Menggunakan Teknologi Informasi dan Komunikasi untuk Kelas X semester 2 SMK Negeri 2 Bandar Lampung. Jakarta: Disertasi Universitas Negeri Jakarta.

Triana, Yuli. Pengajaran Puisi dengan Metode Discovery-inquiry. Padang: Jurnal Universitas Negeri Padang. 